\title{
Growth and Survival Rates of Exploited Coral Reef Fishes in Kenyan Marine Parks Derived From Tagging and Length- Frequency Data
}

\author{
Boaz Kaunda-Arara' and George A. Rose ${ }^{2}$ \\ ${ }^{1}$ Department of Fisheries and Aquatic Sciences, Moi University, P.O. Box 1125, Eldoret, Kenya; \\ ${ }^{2}$ Fisheries Conservation Chair, Marine Institute of Memorial University, P.O. Box 4920, St. John's, NL, AIC \\ 5R3, Canada
}

Key words: Coral reef fishes, fish tagging, absolute growth rates, growth parameters, mortality rates, marine parks, FiSAT, Kenya

\begin{abstract}
Growth increments were obtained from 157 recaptured fishes and yielded estimates of absolute growth rates $\left(\mathrm{cm}^{\mathrm{day}}{ }^{-1}\right)$ for 11 species and growth parameters $(\mathrm{K}, \mathrm{L} \infty$ for 7 species. A total of 3,916 exploited coral reef fishes were tagged within Malindi and Watamu National Marine Parks, Kenya, in 2001 and 2002. Growth rates ranged over an order of magnitude among species. Of the dominant commercial species, the whitespotted rabbitfish, Siganus sutor, had both the highest absolute growth rate $\left(21.9 \pm 14.6 \mathrm{~cm} \mathrm{yr}^{-1}\right)$ and growth coefficient $(\mathrm{K}=1.2$ $\mathrm{yr}^{-1}$ ), whereas emperors (Lethrinus spp.) had somewhat lower rates (overall mean $10.95 \pm 3.65$ $\mathrm{cm} \mathrm{yr}^{-1}$; maximum for $L$. nebulosus, $4.6 \pm 7.3 \mathrm{~cm} \mathrm{yr}^{-1} ; \mathrm{K}=0.92 \mathrm{yr}^{-1}$ ). In contrast, the orangestriped triggerfish, Balistapus undulatus, had an average annual growth rate of only $2.0 \pm 1.9 \mathrm{~cm}$. Growth coefficient (K) estimated for $S$. sutor and the sky emperor, Lethrinus mahsena, using length-frequency analysis (LFA) indicated a lower growth rate $\left(\mathrm{K}=0.54 \mathrm{yr}^{-1}\right)$ for $S$. sutor than derived from tagging, but for $L$. mahsena the LFA-derived growth rate $\left(\mathrm{K}=0.64 \mathrm{yr}^{-1}\right)$ was comparable to the $\mathrm{K}$ derived from tagging $(0.57 /$ year). Growth rates estimated here for most, but not all species ( $L$. mahsena in particular) were similar to those reported from other coral reef regions. Annual survival rates $(S)$ derived from length-converted catch-curves were higher for $S$. sutor $(0.145)$ than for $L$. mahsena $(0.029)$, whereas, natural annual mortality rates (M) were comparable for the species (S. sutor, $1.12 ;$ L. mahsena, 1.25).
\end{abstract}

\section{INTRODUCTION}

Demographic rates are fundamental to fisheries stock assessments and estimation of potential yields (King, 1995; Gallucci et al., 1996). In temperate waters, these rates can be estimated from changes to various parameters over time intervals determined from regular seasonal patterns of skeletal deposits (Weatherley \& Gill, 1987). However, in tropical waters, lack of distinct seasonality has made such analyses more difficult (Sparre \& Venema, 1998), but a number of age and growth estimates, based on annual or daily rings, have been published in recent years (Williams et al., 1995; Pilling et al., 2000; Choat \& Robertson, 2002; Newman \& Dunk, 2002; Pilling et al., in press).

Many coral reef fishes support fisheries in the tropical oceans, but demographic rates have been estimated for relatively few of these (Pauly, 1980; Buesa, 1987; Choat \& Robertson, 2002), in particular in the Caribbean (Munro, 1983) and French Polynesian waters (Ariaz-Gonzalez et al., 1993). In these studies, age and growth have 
typically been estimated from length-frequency analyses (Munro, 1983). However, the influence of environmental factors on growth rates, and the year-round spawning that typifies many tropical species, indicates that independent validation using more than one method of growth estimation would be beneficial (Weatherley \& Gill, 1987; Sparre \& Venema, 1998).

Demographic rates of commercial coral reef species in the Western Indian Ocean are mostly unknown (but see Ntiba \& Jaccarini, 1988; Pilling et al., 2000; Pilling et al,, in press), and estimates from other regions having different environments may not be applicable (Pauly, 1980).

The main objective of this paper is to estimate growth parameters for several important commercially exploited species in the Western Indian Ocean, the most important of which are the whitespotted rabbitfish, Siganus sutor, and Lethrinus mahsena, the sky emperor. Apparent survival rates of these species within two Marine National Parks are also estimated. The estimates are based on both mark-recapture experiments and length-frequency analyses of fishes in coastal Kenya.

\section{MATERIALS AND METHODS}

\section{Study sites}

This work was undertaken in Malindi $\left(6.3 \mathrm{~km}^{2}\right)$ and Watamu $\left(10 \mathrm{~km}^{2}\right)$ Marine National Parks on the Kenyan coast, both created in 1968 (Fig. 1). Malindi Marine Park encloses a continuous fringing reef and patch reef habitats. Watamu Marine Park is located approximately $25 \mathrm{~km}$ south of Malindi and is bounded by a linear fringing reef located $1-2 \mathrm{~km}$ from the shore. Inside the fringing reef is a massive lagoon with islands surrounded by patches of flat eroded inner reef. Reef fisheries in Kenya support approximately 8000 artisanal fishermen who fish between the fringing reefs and shore.

\section{Fish tagging}

Traditional pentagonal shaped "Dema" traps (Kaunda-Arara \& Rose 2004a,b) commonly used in East African coastal fisheries were used to trap fish for tagging. Trapped fish were identified to the lowest taxonomic level possible using field guides from Bock (1978) and Lieske \& Myers (1994), with difficult specimens confirmed using Smith \& Heemstra (1998). Fish less than $14 \mathrm{~cm}$ in total length or species unsuitable for tagging (e.g. muraenids, chaetodontids) were released immediately without tagging. For each fish to be tagged, a serially numbered lock-on spaghetti tag (Floy FD-94, $6 \mathrm{~cm}$ long, orange) was inserted into the dorsal musculature below the dorsal fin using a tagging gun. The tag number was recorded, total length (nearest millimeter) measured and the fish released at the capture point. Fishermen fishing in waters adjacent to the parks were informed of the tagging program prior to the exercise and a reward (Ksh. 100) promised as an incentive to report recapture information. Enthusiasm and participation in the exercise were periodically reviewed during meetings with local fishermen's associations. Tag number, total length (nearest millimeter), date of recapture, recapture location, fisherman's name and gear, were recorded for each recaptured fish. For the whitespotted rabbitfish, Siganus sutor, which is the most important commercial species in the adjacent fisheries, weight $(\mathrm{g})$ was also recorded for recaptured fish. A total of 3916 fish ( 28 species) were tagged inside the parks between February 2001 and March 2002.

Research fish trapping was conducted both inside and outside the two parks. Traps in fished sites adjacent to the parks were set along transects located at geometric intervals $(0,0.2,0.4,0.8,1.6$ and $3.2 \mathrm{~km}$ ) from and parallel to the southern border of the parks. Each fishing event consisted of 2 transects fished with 4-6 traps for 3-4 days. Sampling effort ranged from 7-18 days per trap transect line.

\section{Data analysis}

Growth increment data for seven species of fish including the commercially important S. sutor, and Lethrinus spp. were used to derive growth parameters using the FiSAT package (Gayanilo $e t$ al., 1994). In order to reduce bias caused by handling stress and time-dependent measurement error, only fish at liberty for more than 30 days 


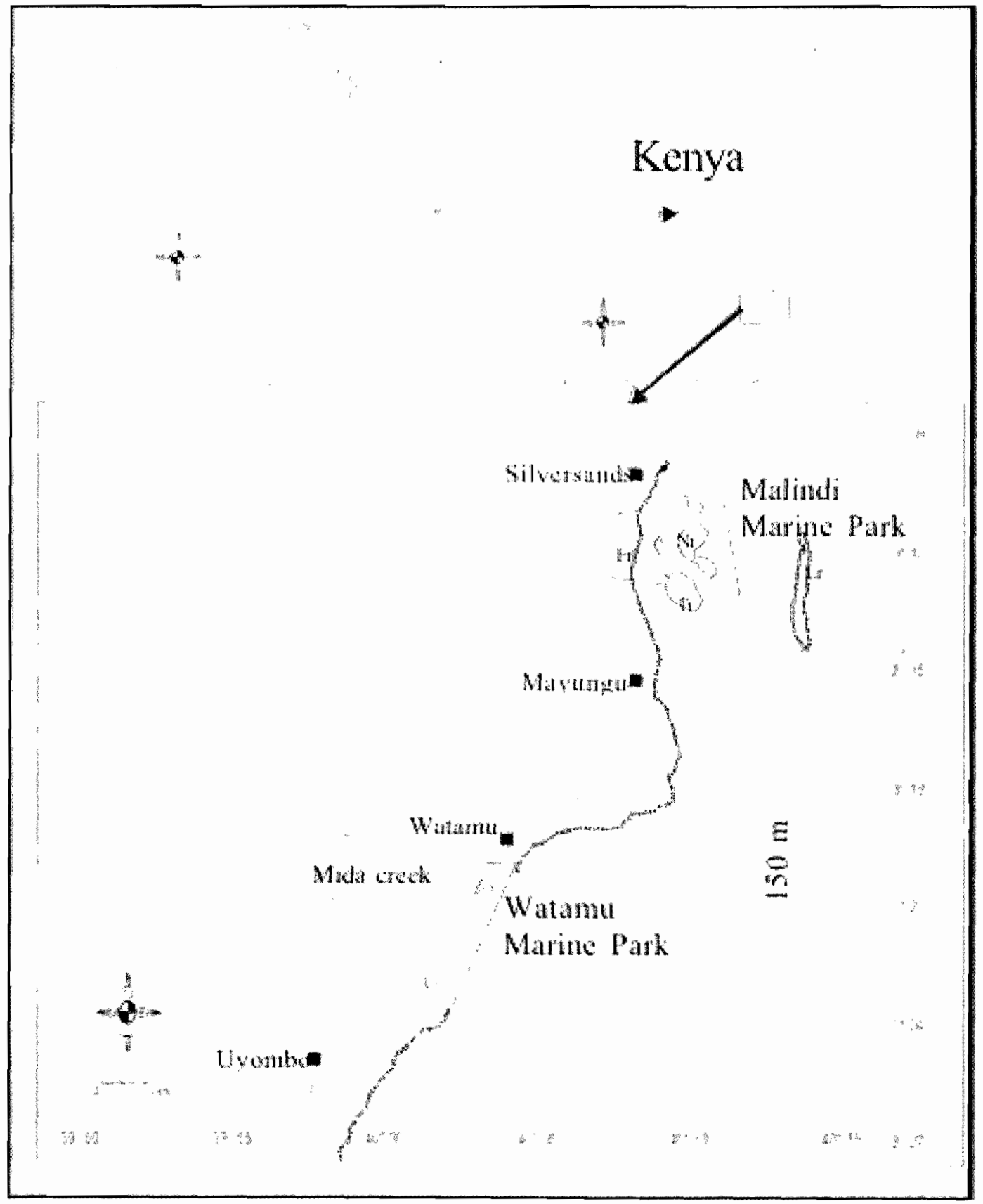

Figure 1. Map of Malindi and Watamu Marine Parks showing the reefs, fish tagging sites ( $)$, the adjacent fished reserves, and the fish landing sites $(\boldsymbol{\sigma})$. NR-North reef, Fr-Fringing reef, Tr-Tewa reef, Lr- Leopard reef 
were utilized for calculation of growth rates. The few fish that had been free for long periods, but had not grown at all, were considered to be affected by the tagging and excluded from analysis. Both fish recaptured in research traps within the parks and those returned by fishermen from outside the parks were utilized in growth estimates. The growth parameters were derived using analytical methods based on the von Bertalanffy growth model:

$\mathrm{L}_{\mathrm{t}}=\mathrm{L}_{\infty}\left[1-\mathrm{e}^{-\mathrm{K}(\mathrm{t}-\mathrm{t}(\mathrm{t})}\right]$

Where $\mathrm{L}_{\mathrm{t}}=$ length at time $\mathrm{t}$ (years), $\mathrm{L}_{\mathrm{r}}=$ asymptotic length $(\mathrm{cm}), \mathrm{K}=$ growth coefficient $\left(\mathrm{yr}^{-1}\right)$ and $t 0=$ hypothetical age when length would be zero. $\mathrm{L}_{\infty}$ was initially estimated from; $\mathrm{L}_{\infty}=0.95 \mathrm{~L}_{\max }$ (Pauly \& Murphy, 1982), where $L_{\max }$ is the size of the largest fish caught. This method gives an initial reference point for subsequent estimates. Following the methodology of Munro (1999), Faben"s routine in FiSAT was then used to obtain a further estimate of $\mathrm{L}_{\infty}$ and the growth coefficient $(\mathrm{K})$ and to help identify any anomalous data. In cases for which resulting estimates of $\mathrm{L}_{\infty}$ were markedly larger than both the initial estimate and known values from the literature, Appeldoorn's method was subsequently used to derive $\mathrm{K}$ with fixed values of $\mathrm{L}_{\infty}$. Munro's method was used to derive the parameters if the sample size was small. In most cases there was convergence of $L_{\infty}$ with initial estimates. The methods have different sensitivity to the variability in the data and sample sizes, this requires that the most robust method be chosen when estimating the growth parameters (J.L. Munro pers. com.).

The phi-prime index, $\phi$, (Pauly \& Munro, 1984), was used to compare growth performance of species for which previous estimates had been made and were available in "Fishbase 98" (Froese \& Pauly, 1998) or the literature.

Further estimates of growth parameters were made for S. sutor and the sky emperor, Lethrinus mahsena, using length frequency analysis (LFA) on fish caught within the parks. To increase modal definition for LFA, samples were pooled trimonthly without weighting and assigned a single collection date. Estimates of the growth coefficient $\mathrm{K}\left(\mathrm{yr}^{-1}\right)$ and asymptotic size $\mathrm{L}_{\infty}(\mathrm{cm})$ were made on the restructured length frequency data using the surface response option in ELEFAN I sub-package in FiSAT and the parameter combination with the highest index of fit $\left(R_{n}\right.$, range $\left.0-1\right)$ selected. Details of the ELEFAN procedures are given in Pauly (1987).

The instantaneous annual total mortality rates (Z) for S. sutor and L, mahsena were calculated using linearized length-converted catch curves following the equation:

$\operatorname{In}\left(\mathrm{N}_{\mathrm{i}} / \mathrm{dt}_{\mathrm{i}}\right)=\mathrm{a}+\mathrm{b} \cdot \mathrm{t}_{\mathrm{i}}$ where $\mathrm{N}$ is number of fish in length class $\mathrm{i}, \mathrm{dt}$ is the time needed for the fish to grow through the length class, $t$ is the relative age (computed with $\mathrm{t}_{\mathrm{o}}=0$ ) corresponding to the mid-length of class $i$ (Pauly, 1984). A regression line was fitted to points immediately to the right of the highest point on the curve. The slope of the line, $b$ (with sign changed), is an estimate of $Z$. Since fishing is not allowed inside the parks, estimates of $Z$ should reflect natural mortality plus emigration rates (see Pinto, 1986). Having derived the growth coefficients $(K)$ and asymptotic lengths $\left(L_{\infty}\right)$, natural mortality rates (M) for $S$. sutor and $L$. mahsena were then estimated following Pauly's (1980) empirical equation;

In $\mathrm{M}=-0.0152-0.279 * \ln \mathrm{L}_{\infty}+0.6543 * \mathrm{In} \mathrm{K}+$ $0.463 * \ln \mathrm{T}$

Where $\mathrm{T}$ (the annual average sea surface temperature) is $27^{\circ} \mathrm{C}$ on the Kenyan coast (Brakel, 1984). As $Z$ is confounded by emigration rates from the parks, estimates of annual survival rates (S) may better reflect population changes within the parks. $S$ was calculated for $S$. sutor and $L$. mahsena as:

$\mathrm{S}=\exp (-Z)$,

following the derivation in Sparre \& Venema (1998).

\section{RESULTS}

Growth rates derived from length changes between tagging and recaptures for fish that had been at large for more than 30 days ranged over an order of magnitude for the different species (Table 1). The orange-striped triggerfish, Balistapus undulatus, peacock grouper, Cephalopholis argus, and blacktip grouper, Ephinephelus fasciatus, had the slowest growth rates $\left(0.005 \pm 0.003 \mathrm{cmd}^{-1}\right)$. The whitespotted rabbitfish, $S$. sutor, showed the fastest growth rate $\left(0.06 \pm 0.04 \mathrm{~cm} \mathrm{~d}^{-1}\right.$ or $21.9 \pm$ $\left.14.6 \mathrm{~cm} \mathrm{yr}^{-1}\right)$ amongst all the species. The three 
Table 1. Absolute growth rates of 11 species of coral reef fishes in coastal Kenya derived from lengths at capture and recapture for fish that had been at liberty for more than 30 days

\begin{tabular}{llllll}
\hline Species & & $\begin{array}{l}\text { Mean size at } \\
\text { capture } \\
(\mathbf{c m}) \pm \mathbf{s . d .}\end{array}$ & $\begin{array}{l}\text { Mean size at } \\
\text { recapture } \\
(\mathbf{c m}) \pm \mathbf{s . d} .\end{array}$ & $\begin{array}{l}\text { Mean days } \\
\text { free } \pm \mathbf{s . d} .\end{array}$ & $\begin{array}{l}\text { Growth rate } \\
\text { (cmday } \mathbf{1} \pm \mathbf{s . d})\end{array}$ \\
\hline Plectorhinchus flavomaculatus & 6 & $26.4 \pm 1.84$ & $29.2 \pm 3.89$ & $100.6 \pm 52.4$ & $0.03 \pm 0.02$ \\
Plectorhinchus gaterinus & 1 & 26.8 & 26.8 & 134 & 0.01 \\
Lethrinus mahsena & 16 & $18.9 \pm 3.20$ & $19.6 \pm 1.83$ & $108.8 \pm 76.6$ & $0.03 \pm 0.03$ \\
Lethrinus miniatus & 6 & $20.7 \pm 1.96$ & $23.3 \pm 3.37$ & $138.2 \pm 109.7$ & $0.02 \pm 0.01$ \\
Lethrinus nebulosus & 6 & $25.8 \pm 6.3$ & $28.9 \pm 4.97$ & $70.3 \pm 85.7$ & $0.04 \pm 0.02$ \\
Siganus sutor & 32 & $19.2 \pm 3.95$ & $22.2 \pm 4.26$ & $61.5 \pm 35.9$ & $0.06 \pm 0.04$ \\
Siganus luridus & 1 & 14.6 & 16.3 & 37.0 & 0.05 \\
Naso hexacanthus & 3 & $23.2 \pm 1.85$ & $26.9 \pm 3.0$ & $148.0 \pm 67.0$ & $0.025 \pm 0.003$ \\
Balistapus undulatus & 6 & $24.3 \pm 4.1$ & $25.3 \pm 3.3$ & $223.2 \pm 94.8$ & $0.005 \pm 0.003$ \\
Cephalopholis argus & 4 & $38.7 \pm 6.8$ & $40.2 \pm 6.3$ & $231.0 \pm 0.0$ & $0.01 \pm 0.002$ \\
Ephinephelus fasciatus & 1 & 27.6 & 28.0 & 46.0 & 0.01
\end{tabular}

species of emperors (Lethrinus spp.) had a mean absolute growth rate of $10.95 \pm 3.65 \mathrm{~cm} \mathrm{yr}^{1}$, with the spangled emperor, L. nebulosus, exhibiting the fastest rate of $0.04 \pm 0.02 \mathrm{~cm} \mathrm{~d}^{-1}$ (or $14.6 \pm 7.3 \mathrm{~cm}$ $\left.\mathrm{yr}^{-1}\right)$.

Length and weight data for S. sutor were obtained at capture from 48 fish released without tagging, and from 26 tagged fish at the time of recapture after being at liberty for more than 30 days. Length-weight relationships for these fish are described by the equations:

Tagged fish: $\quad \mathrm{W}=0.0187^{*} \mathrm{~L}^{2.88} \quad$ (5) and, Untagged fish: $\mathrm{W}=0.032 * \mathrm{~L}^{2.73}$ the two relationships are similar (see Fig. 2), and the length coefficients do not differ significantly $\left(\mathrm{t}_{0.05(2), 70}=1.994, \mathrm{t}=0.28, \mathrm{p}>0.05\right)$ indicating minimal effect of tagging on growth.

For the tagged fish, both the Fabens and Appeldoorn methods in FiSAT indicated a seasonal growth amplitude of $\mathrm{C}=0$ and hence lack of seasonal variation in growth for all species. $S$. sutor had the highest growth coefficient $\left(\mathrm{K}=1.20 \mathrm{yr}^{-1}\right)$ with a fixed $\mathrm{L}_{\infty}$ of $36.30 \mathrm{~cm}$ total length. The estimate of $\mathrm{K}$ for $S$. sutor using LFA in ELEFAN I (Fig. 3a) was lower $\left(0.54 \mathrm{yr}^{-\mathrm{i}}\right)$. However, LFA indicated an $\mathrm{L}_{\infty}$ of $35.7 \mathrm{~cm}$ for $S$. sutor, comparable to that initially estimated from $L_{\max }(36.3 \mathrm{~cm}$, Table 2).

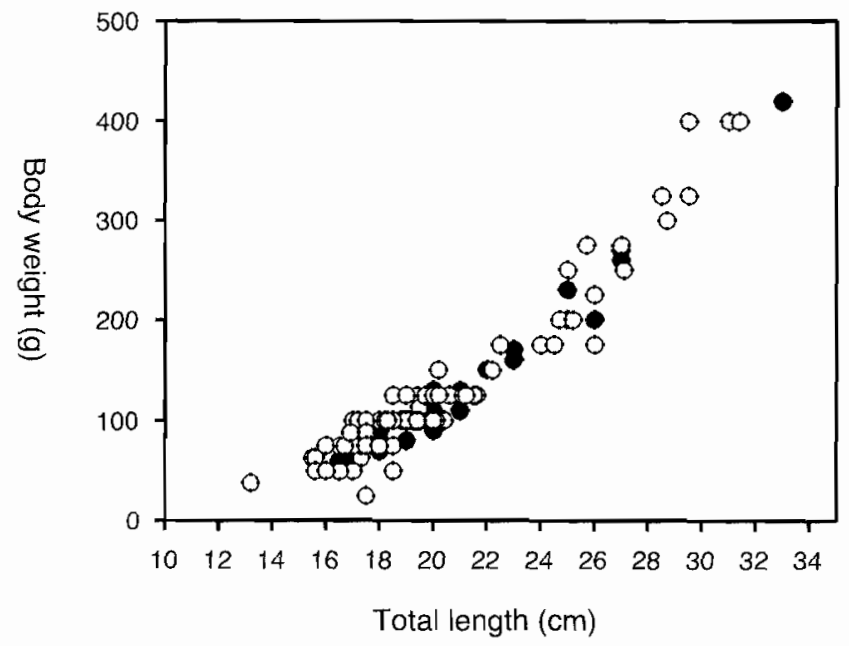

Fig. 2. Length-weight relationships of tagged (O) and untagged (o) whitespotted rabbitfish, Siganus sutor, in coastal Kenya. Tagged data are obtained from fish recaptured in research traps and by fishermen following more than 30 days at liberty, while untagged data are from fish captured but replaced without tagging 
Table 2. Summary of growth parameter estimates for seven species of tagged coral reef fish sampled from Watamu and Malindi Marine Parks, coastal Kenya. $K$ is annual instantaneous growth rate, $\phi^{\prime}$ (phi-prime) is growth performance index, $N$ is sample size, $L_{\infty}$ in brackets are fixed values initially derived from $L_{\infty}=0.95 L_{\max }$

\begin{tabular}{|c|c|c|c|c|c|c|c|c|c|c|c|}
\hline \multirow[t]{2}{*}{ Species } & \multicolumn{4}{|c|}{ Published values } & \multirow[b]{2}{*}{ source } & \multicolumn{6}{|c|}{ Current estimates } \\
\hline & $\mathbf{L}_{\max }$ & $\mathbf{L}_{\infty}$ & $\mathbf{K}$ & $\phi^{\prime}$ & & $L_{\max }$ & $\mathbf{L}_{\infty}$ & $\mathbf{K}$ & $\mathbf{N}$ & $\phi^{\prime}$ & method \\
\hline Siganus sutor & 45 & 36.2 & 1.5 & 3.06 & 1 & 38.2 & $(36.3)$ & 1.20 & 32 & 3.19 & A \\
\hline Lethrinus mahsena & 65 & 28.3 & 0.3 & 2.60 & 2 & 29.5 & $(28.0)$ & 0.57 & 16 & 2.65 & A \\
\hline Lethrinus nebulosus & 86 & 58.5 & 0.7 & 3.41 & 2 & 36.1 & 39.7 & 0.92 & 6 & 3.16 & M \\
\hline Lethrinus miniatus & - & - & - & - & 3 & 44.0 & $(41.8)$ & 0.77 & 6 & 3.13 & $F$ \\
\hline Gaterin flavomaculatus & 60 & - & - & - & 2 & 41.2 & $(39.1)$ & 0.78 & 6 & 3.07 & $\mathrm{M}$ \\
\hline Naso hexacanthus & - & - & - & - & 4 & 38.8 & 32.9 & 1.32 & 3 & 3.20 & $\mathrm{M}$ \\
\hline Balistapus undulatus & 30 & - & - & - & 5 & 29.7 & 28.4 & 0.54 & 6 & 2.64 & $\mathbf{M}$ \\
\hline
\end{tabular}

1. Woodland, (1990); 2. Carpenter and Allen (1989); 3. Masuda et al. (1984); 4. Myers (1991); 5. Matsuura (1979). Methods: A, Appeldoom; M. Munro: F, Fabens.

(a)

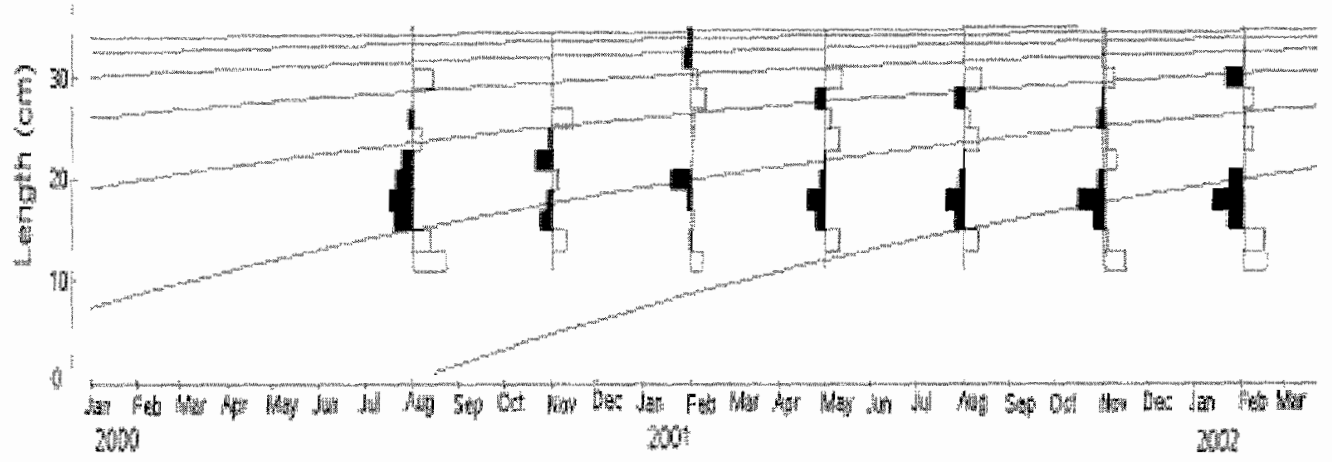

(b)

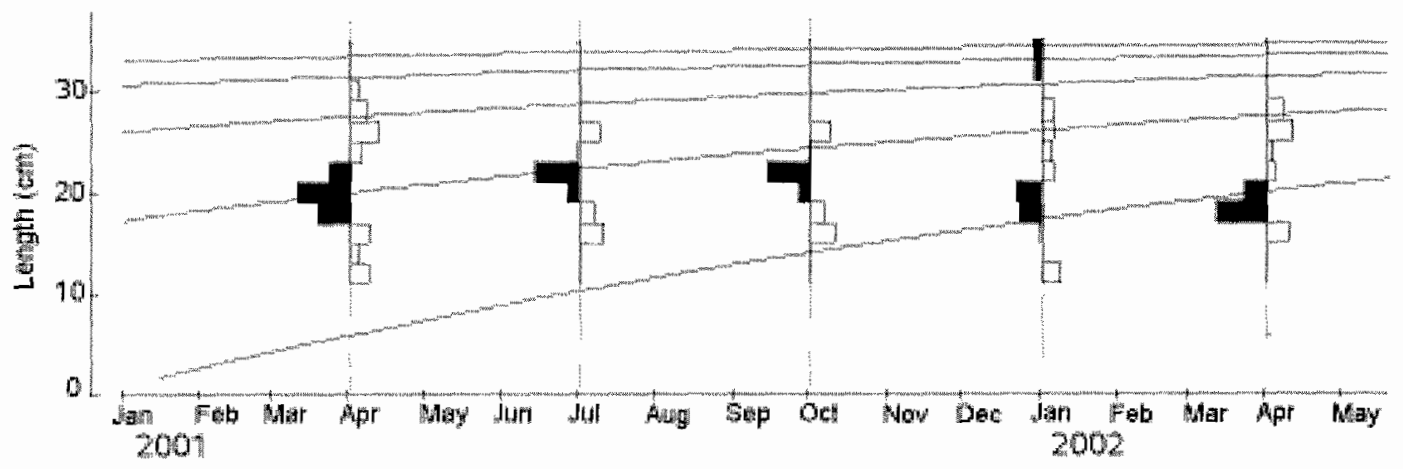

Fig. 3. The growth curves (continuous lines) of cohorts of (a) whitespotted rabbitfish, Siganus sutor, (b) sky emperor, Lethrinus mahsena, in coastal Kenya superimposed over restructured length frequency data. Peaks (black) are positive points and troughs (white) are negative points. Siganus sutor; $R_{t}=0.34, L_{\infty}=35.7 \mathrm{~cm}, \mathrm{~K}=0.54 \mathrm{yr}^{-1}$. Lethrinus mahsena; $R_{\mathrm{n}}=0.42, \mathrm{~L}_{\infty}=35.2 \mathrm{~cm}, \mathrm{~K}=0.64 \mathrm{yr}^{-1}$ Parameters are explained in text 
The emperors had moderate growth rates. with the spangled emperor, L. nebulosus, having the highest $\mathrm{K}\left(0.92 \mathrm{yr}^{-1}\right.$, Table 2$)$. The growth coefficient of $L$. mahsena derived from tagging data was $0.57 \mathrm{yr}^{-1}$, while LFA (Fig. 3b) using ELEFAN I generated a higher but comparable coefficient $\left(K=0.64 \mathrm{yr}^{-1}\right)$ for this species. The
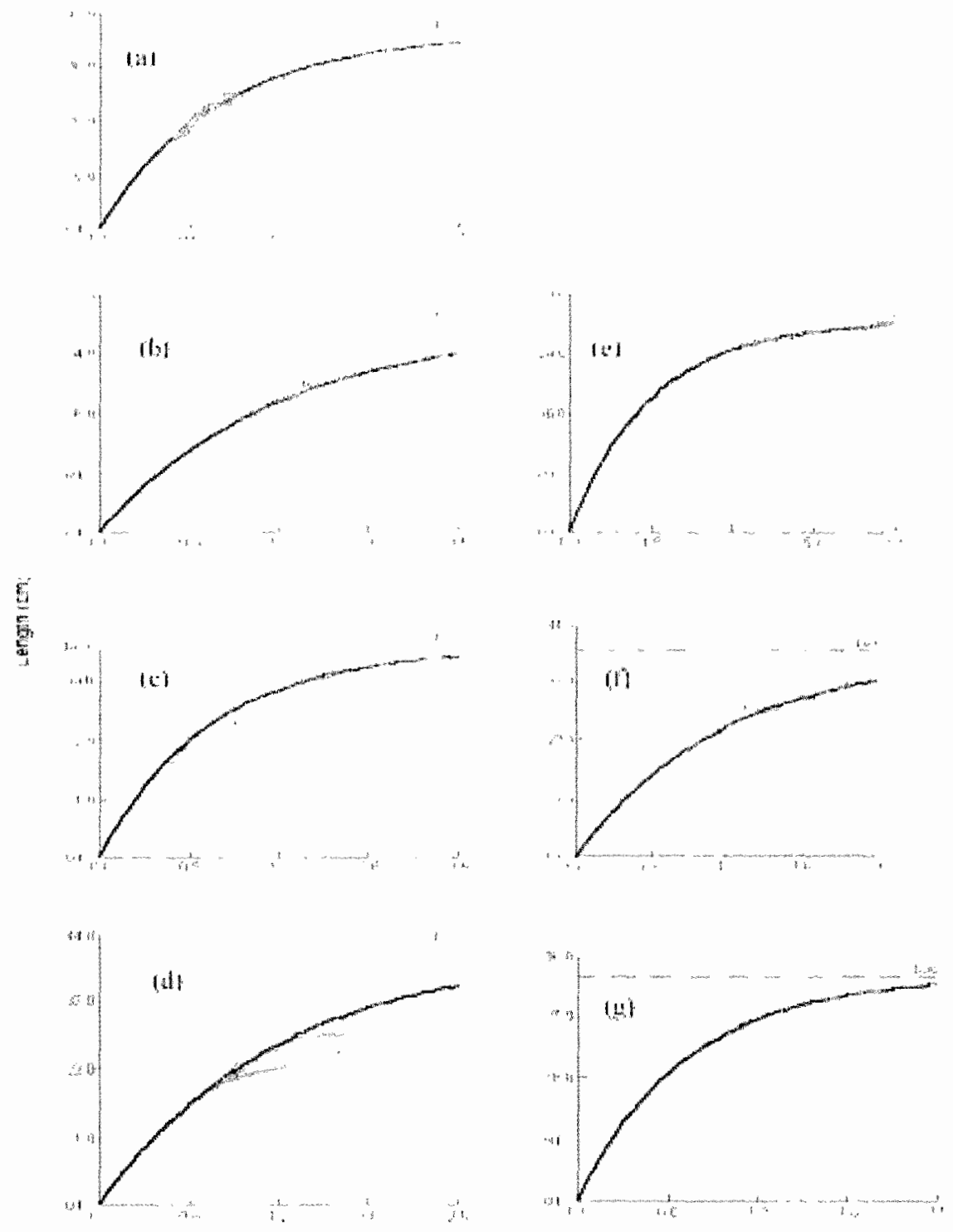

Retative age lyears 10 :

Fig. 4. Growth curves of seven species of exploited coral reef fish based on mark-recapture data from coastal Kenya. Sidelines show deviation of individual growth from the average population growth curve. $L_{\infty}$ is asymptotic length approached by the growth curves for (a) Siganus sutor, (b) Lethrinus mahsena, (c) Lethrinus nebulosus, (d) Lethrinus miniatus, (e) Balistapus undulatus, (f) Plectorhinchus flavomaculatus, and (g) Naso hexacanthus. Growth parameters are given in Table 2 
The annual survival rate ( $S$, equation 4 ) calculated from the slope of the linearized lengthconverted catch curve (equivalent to total mortality rate, Z) (Fig. 5) was lower for the sky emperor $(S=0.029, Z=3.52)$ than for the whitespotted rabbitfish ( $S=0.145, Z=1.93$ ). Given that fishing is not permitted in the parks (i.e., fishing mortality $\mathrm{F}=0$ ), the present estimates of $\mathrm{S}$ and $\mathrm{Z}$ will depend on natural mortality $(\mathrm{M})$ plus emigration from the parks. Annual natural mortality rates (M) of 1.12

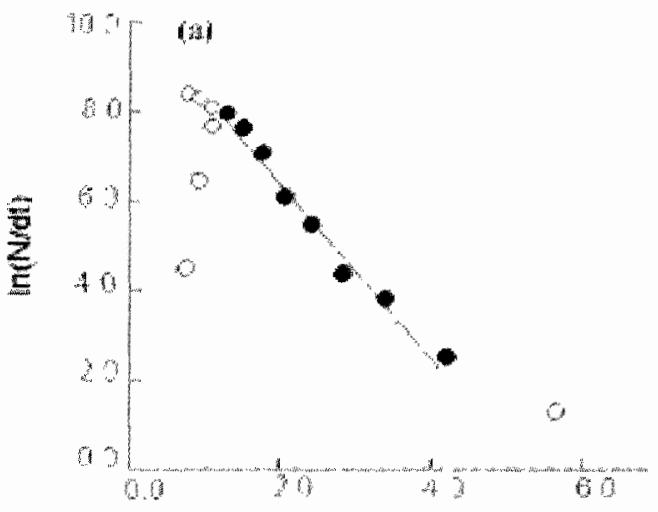

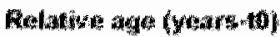

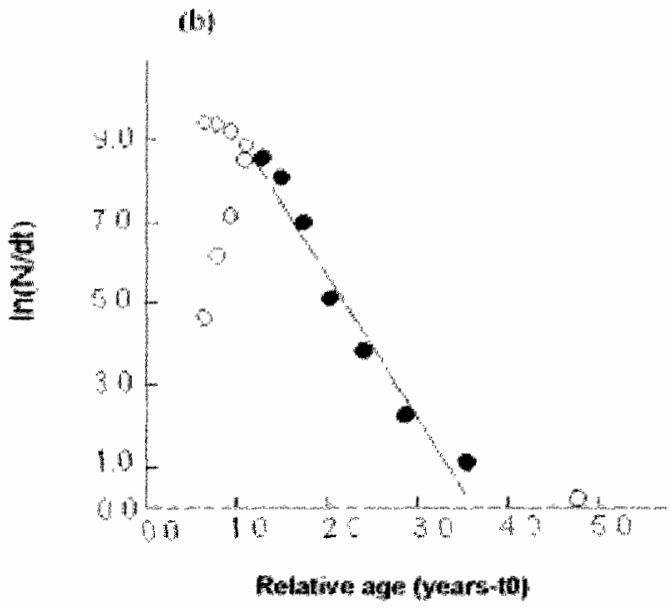

Fig. 5. Linearized length-converted catch curves used to estimate anmual survival rates (S) from the slopes (Z) of the curves in (a) Siganus sutor and (b) Lethrinus mahsena inside Malindi and Watamu Marine Parks, Kenyan. Curves are fitted using ELEFAN II package. $\mathrm{N}$ is number of fish in length class $\mathrm{i}$ and $\mathrm{dt}$ is time needed for fish to grow through the length class. Black cycles were used in the regression, yellow cycles were not because fish are not fully recruited or are close to $L_{\infty}$ Mortality $(Z)$ and survival $(S)$ rates; WSR, $Z=1.93 \mathrm{yr}^{-1}$, $\mathrm{S}=0.145 \mathrm{yr}^{-1} ; \mathrm{SEM}, \mathrm{Z}=3.52 \mathrm{yr}^{-1}, \mathrm{~S}=0.029 \mathrm{yr}^{-1}$ and 1.25 were calculated for $S$. sutor and $L$. mahsena, respectively.

\section{DISCUSSION}

The annual growth coefficient $(K)$ estimated in this study for $S$. sutor averaged 1.2 and was comparable to rates estimated for East African waters by Ntiba \& Jaccarini (1988) based on otolith microstructure $\left(0.9 \mathrm{yr}^{-1}\right)$ and by Woodland (1984) using LFA (1.5 $\left.\mathrm{yr}^{-1}\right)$. Growth performance indices for $S$. sutor from the present and these earlier studies were also comparable. However, the $\mathrm{K}$ estimated presently from LFA $\left(0.54 \mathrm{yr}^{-1}\right)$ was much lower and likely unreliable because of a poor fit of the growth curve to the length-frequency progressions. The better match between the otolith microstructure (Ntiba \& Jaccarini, 1988) and tagging-based estimates of $\mathrm{K}$ (this study) supports the notion that these methods are superior to LFA in estimation of growth rates. LFA-based estimates may be biased by the difficulty in separating length modes in fishes that spawn near year-round in the tropical regions (Sparre \& Venema, 1998) and are often believed to underestimate K (Isaac, 1990).

The $\mathrm{K}$ values estimated for $L$. mahsena from both tagging $\left(0.57 \mathrm{yr}^{-1}\right)$ and LFA $\left(0.64 \mathrm{yr}^{-1}\right)$ were greater than and outside the range $(0.1-0.3)$ previously reported for this species (Froese \& Pauly, 1998). The similarity of K estimated by two independent methods adds credence to the values estimated in the present study. Higher rates in the emperors (the spangled emperor, L. nebulosus, had even a higher rate) than reported from other areas suggest superior conditions for growth in the Kenyan coastal region. There was a paucity of data in the literature on most other species for comparison to presently estimated growth parameters.

For fishes, tagging success will often depend to some extent on the body, skin and scale type of the species. In this study, Siganus sutor was an ideal candidate for tagging, with a low rate of tag loss (Kaunda-Arara \& Rose, 2004b) and little evidence of any effect on growth. Emperors appeared to be more prone to tag loss, but our data are insufficient to assess the potential effect of tagging on growth of this and the several other species. However, the similarity of the $K$ values 
assessed by tagging and LFA is consistent with the notion that for $L$. mahsena, as for $S$, sutor, tagging had little to no effect on growth. However, there were a few fish that had not grown at all over a period of more than 30 days, and these were deemed to have been affected by the tagging and were not included in the analyses. This might have eliminated some slow growing individuals. Nevertheless, the close fit of the data to the general growth curve of most species suggests that the curves are an accurate reflection of growth in the population

Finally, our data suggest that apparent survival rates ( $S$ ) of the two most important species in coastal East African fisheries, the whitespotted rabbitfish and the sky emperor, were quite low within the Malindi and Watamu National Parks. There is no evidence that tagging had any effect on annual survival rates (S), there are no fisheries within the parks and expected natural mortality based on growth characteristics and temperature was similar for both species. The sky emperor shows significant emigration from both parks while the whitespotted rabbitfish emigrates in significant numbers only from the Malindi Park and this may contribute to the low S (Kaunda-Arara \& Rose, $2004 a, b)$. This disparity in movements could perhaps explain the lower apparent survival rate of the sky emperor relative to the rabbitfish, particularly since natural mortality rates were comparable between the two species. In conclusion, this study confirms the usefulness of tagging as a means to better determine demographic rates of commercial fishes that form the basis for stock assessments of many tropical small-scale fisheries (Gallucci et al., 1996). The data on growth parameters and rates presented in this paper should be useful in stock assessment and modeling studies for management of reef fish stocks in the WIO.

Acknowledgments - We are grateful to the Director, Kenya Wildlife Service, for granting permission to tag fish within the marine parks. We thank $M$. Ndegwa, R. Anam, C. Morris, J. Green and C. Mwatete for assistance in the field, Ahmed Shikeli and brothers for coordinating tag returns. We thank the Wardens of Malindi and Watamu Marine National Parks (Messrs. R. Njue and G. Wakaba) for logistic support. Discussion and criticism of Dr. J.L. Munro were very helpful. Funding was received from the International Foundation for Science (IFS, Sweden).

\section{REFERENCES}

Ariaz-Gonzalez, J. E., Galzin, R. \& Torres, F. Jr. (1993). Growth and mortality of Ctenochaetus striatus, Stegastes nigricans and Sargocentron microstoma in Tiahura Reef. Moorea Island, French Polynesia. Naga, 16: 32-35.

Bock, K. (1978). A guide to common reeffishes of the western Indian Ocean \& Kenya Coast. Macmillan press Ltd., London, 118pp.

Brakel, W. H. (1984). Seasonal dynamics of suspended-sediment plumes from the Tana and Sabaki rivers, Kenya. Analysis of landsat imagery. Remote Sensing of environment 16: 165-173.

Buesa, R. J. (1987). Growth rate of tropical demersal fishes. Mar. Ecol. Prog. Ser. 36: 191-199.

Carpenter, K. E. \& Allen, G.R. (1989). FAO species catalogue vol.9. Emperor fishes and large-eye breams of the world (family: Lethrinidae). FAO species synop. No. 125, 118p.

Choat, J.H. \& Robertson, D.R. (2002). Age -based studies . In Coral Reef Fishes (P.F. Sale, ed.), pp. 57-80. Elsevier Science, USA.

Gallucci, V.F., Amjou, B., Hedgepeth, J.B. \& Lail, HL. (1996). Size-based methods of stock assessment of small-scale fisheries. In Stock Assessment : Quantitative methods and applications for small scale fisheries (Gallucci, V.F., Saila, S.B., Gustafson, D.J. \& Rothschild, B.J., eds), pp. 981. CRC Lewis Publishers Boca Raton, USA.

Gayanilo Jr., F.C., Sparre, P. \& Pauly, D. (1994). The FAO-ICLARM stock assessment Tools (FiSAT) user's guide. FAO computerized Information Series (Fisheries) No. 8 Rome, FAO, 124p

Froese, R. \& Pauly, D. (eds.) (1998). Fishbase 4B: Concepts, Designs and data devices. ICLARM, Manila, Philippines. 293p.

Isaac, V. J. (1990). The accuracy of some length-based methods for fish population studies. ICLARM Technical Report, 27.

Kaunda-Arara, B. \& Rose, G.A. (2004a). Effects of marine reef National Parks on fishery CPUE in coastal Kenya. Biol. Cons. 118: 1-13.

Kaunda-Arara, B. \& Rose, G.A. (2004b). Outmigration of tagged fishes from marine reef National Parks to fisheries in coastal Kenya. Environ. Biol. Fish. 70: 363-372.

King, M. (1995). Fisheries Biology, Assessment and Management. Fishing news Book, Blackwell, Victoria Australia. 338p. 
Lieske, E. \& Myers, R. (1994). Coral reef fishes: Caribbean, Indian Ocean and Pacific Ocean. HarperCollins, London.

Masuda, H., Amaoka, K., Araga, C., Uyeno, T. \& Yoshino, T. (1984). The fishes of the Japanese Archipelago. Tokad Univ. Press, Tokyo, Japan. $37 \mathrm{pp}$.

Matsuura, K . (1979). Balistidae, triggerfishes. In FAO identification Guide for fishery purposes (Carpenters, K.E. \& Niem, V. eds.).

Munro, J. L. (1983). Caribbean coral reef fishery resources. ICLARM studies and reviews 7, Manila, Philippines.

Munro, J. L. (1999). Marine Protected Areas and the management of Coral reef Fisheries. ICLARM technical report. 40p.

Myers, R.F. (1991). Micronesian reef fishes. Second Ed. Coral Graphics, Barrigada, Guam. 298p.

Newman, S.J. \& Dunk, I.J. (2002). Growth, age validation, mortality and other population characteristics of the red emperor snapper, Lutjanus sebae (Cuvier, 1828), off the Kimberley coast of north-western Australia. Estuar. Coast. Shelf Sci. 55: 67-80.

Ntiba, M. J. \& Jaccarini, V. (1988). Age and growth parameters of Siganus sutor in Kenyan matine waters, derived from numbers of otolith microbands and fish lengths. J. Fish Biol. 33: 465470.

Pauly, D. (1980). On the interrelationships between natural mortality, growth parameters, and mean environmental temperature in 175 fish stocks. $J$. Cons.expl. mer. 39: 175-192.

Pauly, D. (1984). Length-converted catch curves. A powerful tool for fisheries research in the tropics. Part II. ICLARM Fishbyte 1: 17-19.

Pauly, D. (1987). A review of the ELEFAN system for analysis of length-frequency data in fish and aquatic invertebrates. ICLARM Conf. Proc. 13: 734.
Pauly, D. \& Munro, J.L. (1984). Once more on the comparison of growth in fishes and invertebrates. ICLARM Fishbyte 2: 5-6

Pauly, D. \& Murphy, G. I. (eds.) (1982). Theory and management of tropical fisheries. Proceedings of the ICLARM/CSIRO workshop on the theory and management of tropical multispecies stocks. ICLARM Conf. Proc. 9: $360 \mathrm{pp}$.

Pilling, G.M., Millner, R.S., Easey, M.W., Mees, C.C., Rathacharen, S. \& Azemia, R. (2000). Validation. of annual growth increments in the otoliths of the lethrinid Lethrinus mahsena and the lutjanid Aprion virescens in the tropical Indian Ocean, with notes on the nature of growth increments in Pristipomoides filamentosus. Fish. Bull. U.S. 98: 600-611.

Pilling, G.M., Grandcourt, E.M. \& Kirkwood, G.P. in press. The utility of otolith weight as a predictor of age in the emperor Lethrinus mahsena and other tropical fish species. Fisheries Research: 14pp.

Pinto, L. (1986). Use of ELEFAN programs for emigrating species. Fishbyte 4: 14-15.

Smith, J. L. B. \& Heemstra, P.C. (1998). Smith's Sea Fishes. Valiant Publ. Sandton. South Africa. Fourth edition, $578 \mathrm{pp}$.

Sparre, P. \& Venema, S. C. (1998). Introduction to tropical fish stock assessment. Part 1 manual. FAO Fisheries Technical Paper 306/1. 407p.

Weatherley, A. H. \& Gill, H. S. (1987). The Biology of fish growth. Academic Press, London, 443pp.

Williams, DMcB., Newman, S. J., Cappo, M. \& Doherty, P.J. (1995). Recent advances in the ageing of coral reef fishes. Proc. South Pacific Commission workshop on the management of South Pacific inshore Fisheries, Noumea. pp 667671.

Woodland, D.J. (1990). Family Siganidae. In FAO Species identification Sheets for fishery purposes: Western Indian Ocean (Fishing Area 51) (W. Fischer \& G. Bianchi, eds), vol. IV. Rome: FAO. 